\title{
Microcrystalline silicon solar cells with an open-circuit voltage above $600 \mathrm{mV}$
}

M. N. van den Donker, S. Klein, B. Rech, F. Finger, W. M. M. Kessels, and M. C. M. van de Sanden

Citation: Appl. Phys. Lett. 90, 183504 (2007);

View online: https://doi.org/10.1063/1.2734375

View Table of Contents: http://aip.scitation.org/toc/apl/90/18

Published by the American Institute of Physics

\section{Articles you may be interested in}

Determining the material structure of microcrystalline silicon from Raman spectra Journal of Applied Physics 94, 3582 (2003); 10.1063/1.1596364

Complete microcrystalline $\mathrm{p}-\mathrm{i}-\mathrm{n}$ solar cell-Crystalline or amorphous cell behavior?

Applied Physics Letters 65, 860 (1994); 10.1063/1.112183

Crystal size and temperature measurements in nanostructured silicon using Raman spectroscopy Journal of Applied Physics 90, 4175 (2001); 10.1063/1.1398601

Plasma deposition of optical films and coatings: A review Journal of Vacuum Science \& Technology A: Vacuum, Surfaces, and Films 18, 2619 (2000); 10.1116/1.1314395

Evolution of the microstructure in microcrystalline silicon prepared by very high frequency glow-discharge using hydrogen dilution

Journal of Applied Physics 87, 3137 (2000); 10.1063/1.372311

Reversible conductivity changes in discharge-produced amorphous $\mathrm{Si}$

Applied Physics Letters 31, 292 (1977); 10.1063/1.89674

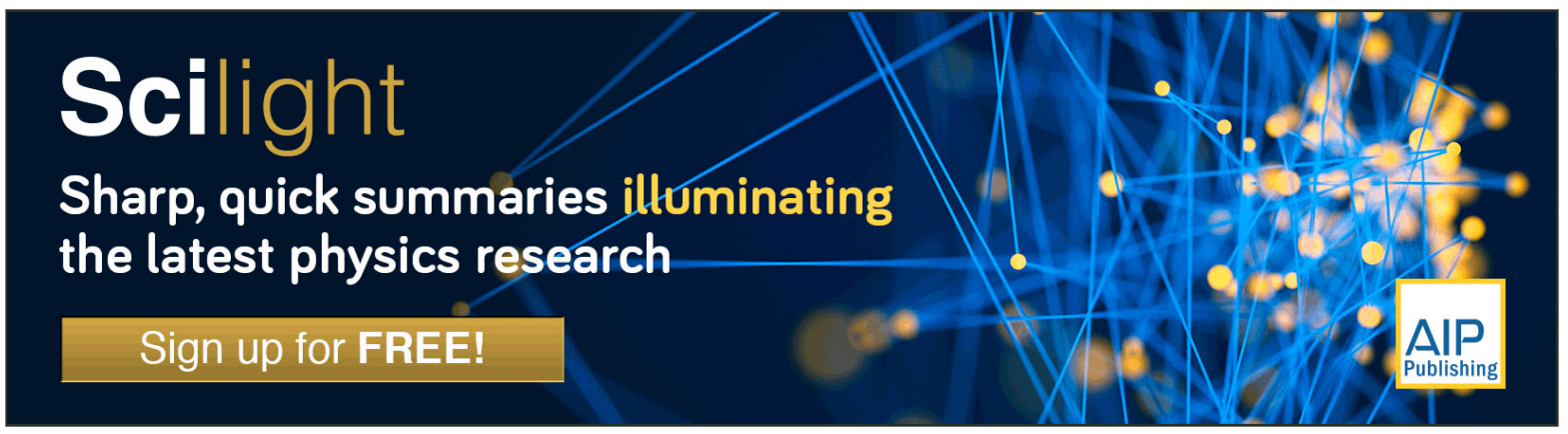




\title{
Microcrystalline silicon solar cells with an open-circuit voltage above $600 \mathrm{mV}$
}

\author{
M. N. van den Donker, ${ }^{\text {a) }}$ S. Klein, ${ }^{\text {b) }}$ B. Rech, ${ }^{\text {c) }}$ and F. Finger ${ }^{\text {d) }}$ \\ IEF-5 Photovoltaik, Forschungszentrum Juelich GmbH, 52425 Juelich, Germany
}

W. M. M. Kessels and M. C. M. van de Sanden

Department of Applied Physics, Eindhoven University of Technology, P.O. Box 513, 5600 MB Eindhoven, The Netherlands

(Received 18 February 2007; accepted 31 March 2007; published online 30 April 2007)

\begin{abstract}
Microcrystalline silicon solar cells with an open-circuit voltage surpassing the $600 \mathrm{mV}$ barrier were prepared by combining the use of a hot wire deposited $p-i$ interface with that of an $i$ layer deposited by radio-frequency parallel plate plasma deposition using controlled $\mathrm{SiH}_{4}$ flow profiling. The control of the bulk and interface properties facilitated effective charge carrier collection from $i$ layers with a crystalline volume fraction as low as $\sim 30 \%$. Judging from the absorption in the infrared and the excellent charge carrier transport, the optoelectronic properties of this material were still dominated by the crystalline rather than the amorphous phase. (C) 2007 American Institute of
\end{abstract} Physics. [DOI: 10.1063/1.2734375]

Microcrystalline silicon $(\mu \mathrm{c}-\mathrm{Si}: \mathrm{H})$ consists of $\sim 10 \mathrm{~nm}$ sized $^{1}$ crystalline silicon $(c$-Si) grains embedded in a columnar structure and surrounded by amorphous silicon $(a-\mathrm{Si}: \mathrm{H})$. The multitude of grain boundaries associated with this heterogeneous material composition makes grain boundary passivation of utmost importance to obtain any electronically high grade material. With respect to application of silicon in solar cells, the grain boundary passivation mainly affects the open-circuit voltage $\left(V_{\mathrm{oc}}\right)$. $^{2}$ The scientific challenge of controlling the interface passivation thus coincides with the technological development towards higher $V_{\text {oc }}$ in solar cells.

Figure 1 shows the progress made in $\mu \mathrm{c}-\mathrm{Si}: \mathrm{H}$ solar cell technology over the years in terms of the $V_{\mathrm{oc}}$. The first $\mu \mathrm{c}-\mathrm{Si}: \mathrm{H}$ solar cells, prepared in the $1990 \mathrm{~s}$ with a crystalline volume fraction typically above $80 \%$, yielded a $V_{\text {oc }}$ around $400 \mathrm{mV} .^{3-6}$ In 2000 , Vetterl et al. presented $\mu \mathrm{c}-\mathrm{Si}: \mathrm{H}$ solar cells with a lower crystalline volume fraction of $60 \%$ that showed an improved $V_{\text {oc }}$ of $520 \mathrm{mV}^{7}$ Even $V_{\text {oc }}$ values higher than $520 \mathrm{mV}$ were obtained, for crystalline volume fractions lower than $60 \%$, however, at the cost of a sharp drop in fill factor $(\mathrm{FF})$ and short-circuit current density $\left(J_{\mathrm{sc}}\right)$. A plausible explanation is that the grain boundaries in the $\mu \mathrm{c}-\mathrm{Si}: \mathrm{H}$ are increasingly well passivated by the amorphous volume fraction up to a certain threshold fraction. When passing this threshold fraction the optoelectronic properties of the material become $a-\mathrm{Si}: \mathrm{H}$ dominated with a corresponding low hole mobility and low infrared absorption.

For some years it appeared that the $V_{\mathrm{oc}}$ at which maximum solar energy conversion efficiency is obtained, the socalled best-cell $V_{\text {oc }}$, was limited to the $520 \mathrm{mV}$ range. $^{7-11}$ However, in 2002 a best-cell $V_{\text {oc }}$ of $580 \mathrm{mV}$ was reported for $\mu \mathrm{c}-\mathrm{Si}: \mathrm{H}$ solar cells prepared by hot wire deposition. ${ }^{12}$ For

\footnotetext{
${ }^{a)}$ Present address: Solland Solar Cells BV, Bohr 10, 6422 RL, Heerlen, The Netherlands.

${ }^{b)}$ Present address: Applied Materials, Siemensstr. 100, 62755 Alzenau, Germany.

${ }^{c}$ Present address: Department Silicon Photovoltaics (SE1), Hahn-MeitnerInstitut Berlin, Kekuléstraße 5, 12489 Berlin, Germany.

${ }^{d)}$ Author to whom correspondence should be addressed; electronic mail: f.finger@fz-juelich.de
}

very high frequency (VHF) plasma-deposited solar cells a best-cell $V_{\text {oc }}$ around $570 \mathrm{mV}$ was reported in 2005 by the application of a hot wire (HW) deposited buffer layer between the $p$ and $i$ layers. ${ }^{13}$ For radio-frequency (rf) plasma deposition, a best-cell $V_{\text {oc }}$ around $560 \mathrm{mV}$ was reported in 2005 using a $\mathrm{SiH}_{4}$ flow profiling technique. ${ }^{14}$ Using a similar $\mathrm{SiH}_{4}$ profiling technique, a best-cell $V_{\text {oc }}$ around $570 \mathrm{mV}$ was reported in 2006 for modified VHF deposition. ${ }^{15}$ These recent advancements indicate that there is still room for improvement in the technological development towards higher $V_{\mathrm{oc}}$.

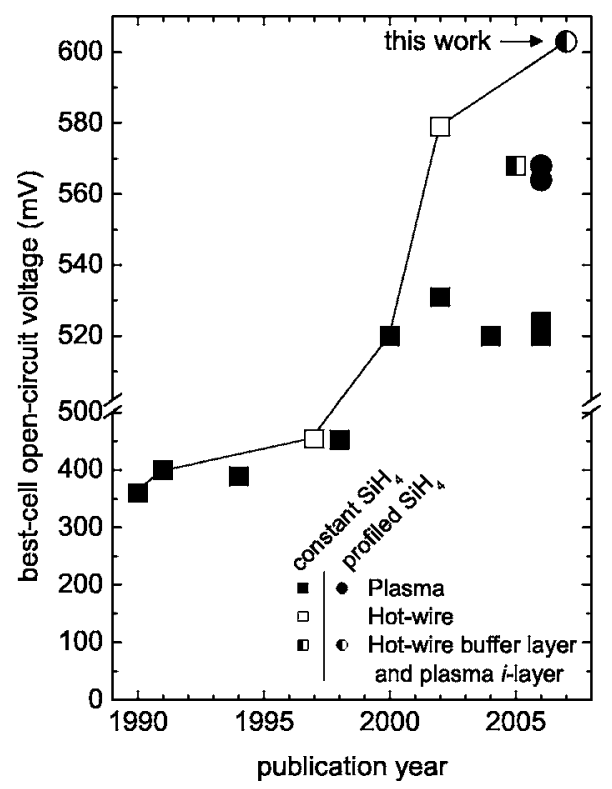

FIG. 1. Progress made in the best-cell $V_{\mathrm{oc}}$ of $\mu \mathrm{c}=\mathrm{Si}: \mathrm{H}$ solar cells for plasma deposition (closed symbols), hot wire deposition (open symbols), and combined hot wire deposition of a buffer layer and plasma deposition of the $i$ layer (half-open symbols). Data between 1990 and 1999 concern the initial efforts $\mu \mathrm{c}-\mathrm{Si}: \mathrm{H}$ solar cells (squares, Refs. 3-6), whereas the data between 2000 and 2006 concern solar cells with $\mu \mathrm{c}-\mathrm{Si}: \mathrm{H}$ material of optimized crystalline volume fraction (squares, Refs. 7-13). The data using a profiled $\mathrm{SiH}_{4}$ flow (circles) refer to Refs. 14 and 15 and this work. The solid line connects the best-cell $V_{\text {oc }}$ values obtained over time as a guide to the eyes. 
In this letter we report on $\mu \mathrm{c}-\mathrm{Si}: \mathrm{H}$ solar cells reaching a $V_{\text {oc }}$ that surpasses the $600 \mathrm{mV}$ barrier. A best-cell $V_{\text {oc }}$ of $603 \mathrm{mV}$ was obtained by a combined approach: (i) controlling the $p-i$-interface properties using a HW deposited buffer layer and (ii) controlling the $i$-layer bulk properties by $\mathrm{SiH}_{4}$ flow profiling during the rf parallel plate plasma deposition process. By this approach the $V_{\mathrm{oc}}$ of $\mu \mathrm{c}-\mathrm{Si}: \mathrm{H}$ solar cells comes closer to the values obtained in the best monocrystalline [706 mV (Ref. 16)], amorphous/crystalline heterojunction [702 mV (Ref. 17)], and multicrystalline [664 mV (Ref. 18)] silicon solar cells. It may thus be regarded as an important step in the progress towards highly efficient thin film silicon solar cells.

The $p-i-n$ solar cells were fabricated on texture-etched ZnO:Al coated glass ${ }^{8,19}$ of $10 \times 10 \mathrm{~cm}^{2}$ in size. The $\mu \mathrm{c}-\mathrm{Si}: \mathrm{H}$ $p$ and $i$ layers and $a-\mathrm{Si}: \mathrm{H} n$ layers were deposited by 13.56 MHz rf parallel plate plasma deposition in a multichamber vacuum system. ${ }^{20,21}$ A second multichamber vacuum system was used for the deposition of $\mu \mathrm{c}-\mathrm{Si}: \mathrm{H} p$ layers by VHF parallel plate plasma deposition and $\mu \mathrm{c}-\mathrm{Si}: \mathrm{H}$ buffer layers by hot wire deposition. ${ }^{13}$ For all cells, the $i$-layer thickness ranged from 1.0 to $1.5 \mu \mathrm{m}$. $\mathrm{ZnO} / \mathrm{Ag}$ backcontacts of $1 \times 1 \mathrm{~cm}^{2}$ in size defined the aperture area of the solar cells. A class A double-source solar simulator was used for solar cell characterization. Raman scattering measurements were carried out with $647 \mathrm{~nm}$ laser light to obtain the semiquantitative measure $I_{c}^{\mathrm{RS}}$ for the average crystalline volume fraction of the $i$ layer, after etching off the $n$ layer with potassium hydroxide. The contribution of the crystalline grains to the Raman scattered signal was determined by subtracting an $a-\mathrm{Si}: \mathrm{H}$ reference spectrum. ${ }^{22}$

Figure 2 shows the conversion efficiency $\eta$, fill factor $(\mathrm{FF})$, and short-circuit current $J_{\mathrm{sc}}$ plotted versus $V_{\mathrm{oc}}$ for four series of depositions labeled "reference," "hot wire buffer," " $\mathrm{SiH}_{4}$ profiling," and "buffer+ profiling." The different values for the $V_{\mathrm{oc}}$ in each series were obtained by varying the (timeaveraged) $\mathrm{SiH}_{4}$ flow at which the $i$ layer was deposited. The measured solar cell and film properties at the best-cell $V_{\mathrm{oc}}$ are stated in the legend. The reference series was prepared without vacuum break in the $\mathrm{H}_{2}$ diluted rf high pressure depletion regime. ${ }^{20,21}$ In the hot wire buffer series, a hot wire deposited buffer layer with a thickness of $\sim 15 \mathrm{~nm}$ was prepared under low pressure, low deposition rate, low filament temperature conditions ${ }^{13}$ while, after transport through air, the $i$ and $n$ layers were deposited under equal conditions as for the reference series. Since the VHF deposited $p$ layer in these cells was slightly thinner than the $p$ layer in the reference series, the current for this series was slightly higher and the fill factor slightly lower. The $\mathrm{SiH}_{4}$ profiling series was rf deposited using an undiluted feed gas flow (i.e., consisting solely of $\mathrm{SiH}_{4}$ ) that was gradually increased during deposition by $\sim 20 \%$ in order to keep the plasma's optical emission intensity constant. ${ }^{14}$ In the buffer+profiling series, deposition of the $p$ layer and HW buffer layer took place under equal conditions as the hot wire buffer series whereas the deposition of the $i$ and $n$ layers took place under equal conditions as the $\mathrm{SiH}_{4}$ profiling series.

For each series in Fig. 2 one can clearly distinguish a best-cell $V_{\text {oc }}$ at which maximum solar energy conversion efficiency is obtained. Application of the HW buffer layer and application of the controlled $\mathrm{SiH}_{4}$ profiling technique both enhance the best-cell $V_{\text {oc }}$, from $533 \mathrm{mV}$ for the reference series to 550 and $564 \mathrm{mV}$ for the hot wire buffer and $\mathrm{SiH}_{4}$

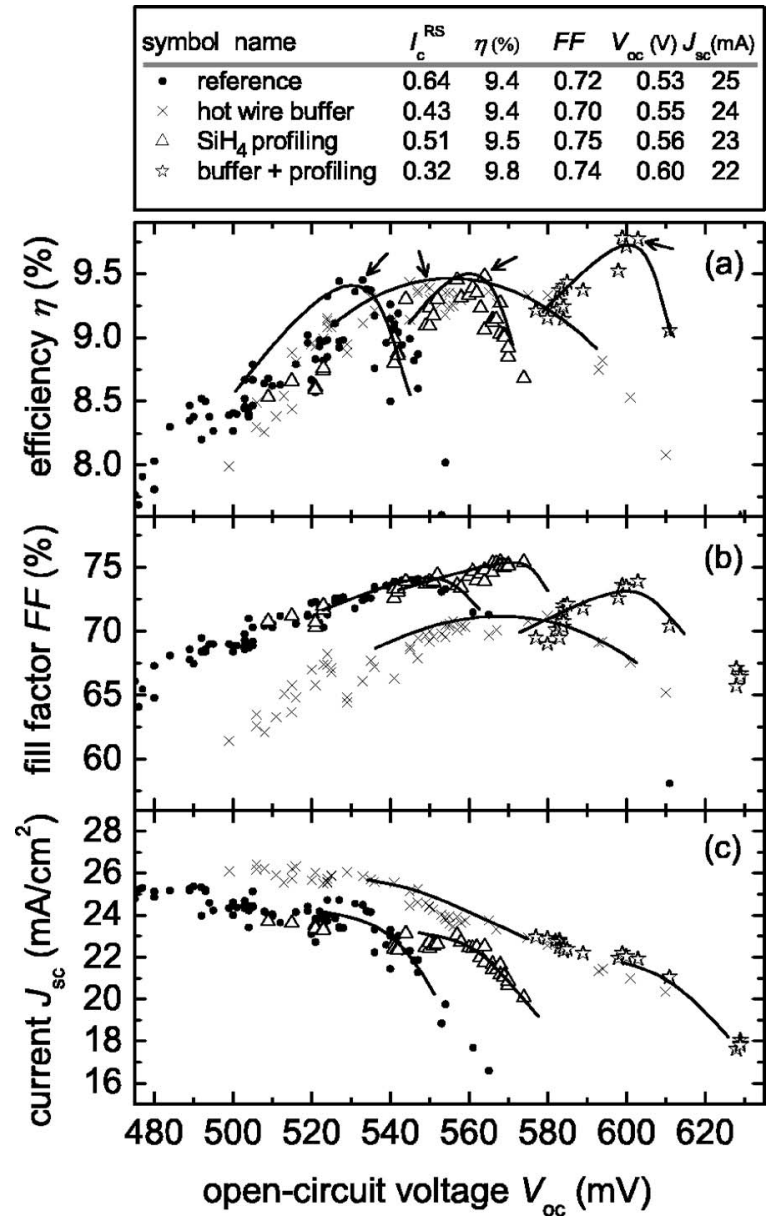

FIG. 2. Solar cell parameters: (a) efficiency $\eta$, (b) fill factor (FF), and (c) short-circuit current density $J_{\mathrm{sc}}$ vs the open-circuit voltage $V_{\mathrm{oc}}$, in a reference series using rf plasma deposition (dots), incorporating a hot wire deposited buffer layer (crosses), incorporating controlled $\mathrm{SiH}_{4}$ flow profiling (triangles), and incorporating both a hot wire deposited buffer layer and controlled $\mathrm{SiH}_{4}$ flow profiling (stars). The trends of the four series around the best-cell $V_{\mathrm{oc}}$ are indicated by solid lines as a guide to the eyes. The legend summarizes the best-cell parameters for the solar cells indicated by arrows in (a).

profiling series, respectively. The Raman characterization indicates that in both series the enhanced best-cell $V_{\mathrm{oc}}$ is accompanied by a decrease in best-cell $I_{c}^{\mathrm{RS}}$, from $64 \%$ for the reference series to $43 \%$ and $51 \%$ for the hot wire buffer and $\mathrm{SiH}_{4}$ profiling series, respectively.

By simultaneously applying a HW buffer and controlled $\mathrm{SiH}_{4}$ profiling a best-cell $V_{\text {oc }}$ of $603 \mathrm{mV}$ was obtained with a best-cell $I_{c}^{\mathrm{RS}}$ of $32 \%$. The reasonably good red and near infrared absorption $\left(J_{\mathrm{sc}}=22 \mathrm{~mA} / \mathrm{cm}^{2}\right)$ and excellent electronic transport properties $(\mathrm{FF}=74 \%)$ indicate that the optoelectronic properties of this material were still determined by the crystalline rather than the amorphous volume fraction. Figure 3 compares the external quantum efficiency (EQE) for cells with different $V_{\text {oc }}$ values. From Fig. 3(a) it is evident that in the reference series, both blue and near infrared responses drop sharply above the best-cell $V_{\text {oc }}$ of $533 \mathrm{mV}$. By the application of the hot wire buffer and the $\mathrm{SiH}_{4}$ profiling, the drop in blue response is prevented completely and the drop in the near infrared is reduced significantly. One may thus tentatively conclude that the hole collection near the $p-i$ interface and the hole mobility near the $i-n$ interface have significantly been improved, thus allowing the efficient 


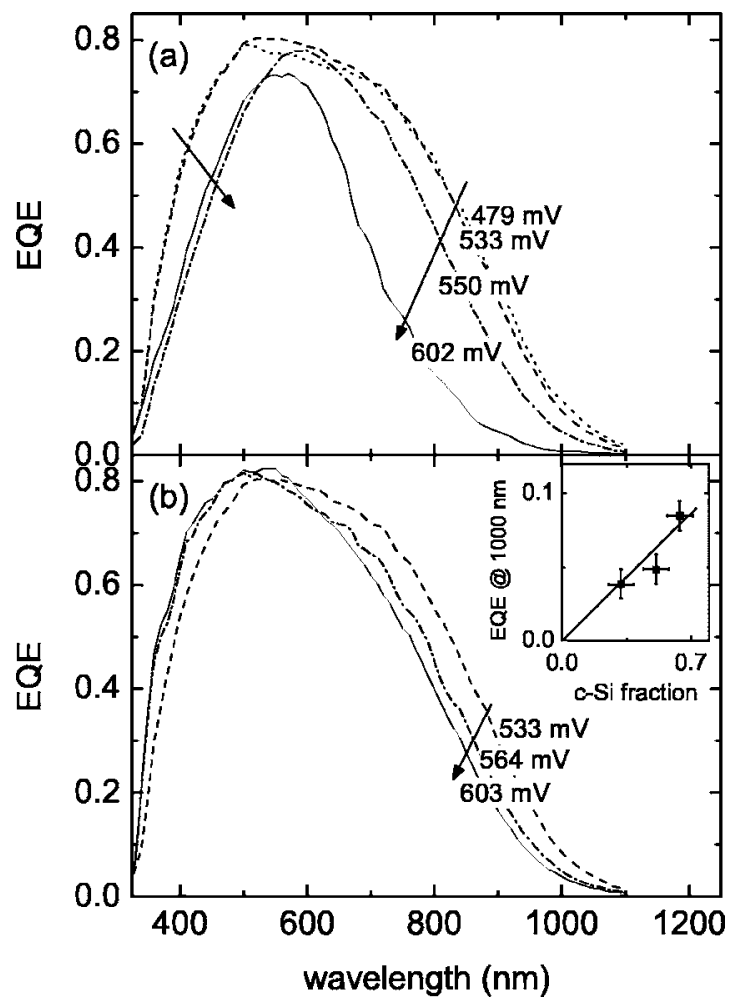

FIG. 3. Comparison of the external quantum efficiency (EQE) of solar cells with various open-circuit voltages: (a) cells from the "reference" series and (b) best cells from the reference, " $\mathrm{SiH}_{4}$ profiling," and "buffer+profiling" series. The inset in (b) shows the EQE at $1000 \mathrm{~nm}$ as a function of the crystalline volume faction of the $i$ layer.

charge carrier collection at this low crystalline volume fraction of $32 \%$.

In contrast to the collection efficiency, the generation of charge carriers was not maintained at low crystalline volume fraction. Namely, Fig. 2 indicates that throughout all four data series there is a trend of decreasing $J_{\text {sc }}$ with increasing $V_{\text {oc }}$. Figure 3(b) and inset show that this trend originates from a linearly decreasing infrared response with decreasing crystalline volume fraction. We may conclude that the high amorphous volume fraction that is necessary to obtain a high $V_{\text {oc }}$ simultaneously results in a lower $J_{\text {sc }}$.

Finally, from the high amorphous volume fraction of the best solar cell from the buffer+profiling series one might expect considerable light induced degradation. For solar cells with a crystalline volume fraction of 30\%-40\% Klein et al. ${ }^{23}$ who investigated hot wire deposited solar cells, and Wang et al. ${ }^{24}$ who investigated plasma-deposited solar cells with hot wire buffer layer, both found a degradation in efficiency of around $8 \%$ after $1000 \mathrm{~h}$ of AM 1.5 white light illumination under open-circuit conditions. We therefore expect the degradation of the solar cells presented in this work to lie in the same range. In this respect it is important to point out that the single junction $\mu \mathrm{c}-\mathrm{Si}: \mathrm{H}$ degradation does not hold clear consequences for degradation of a $\mu \mathrm{c}-\mathrm{Si}: \mathrm{H}$ bottom cell in a tandem structure. Namely, a bottom cell would receive considerably less blue and green light. Absorption in this case will take place mainly in the crystalline volume fraction. Since it is energetically highly unfavorable for charge carriers that are generated within the crystalline grains to enter band or band-tail states of the amorphous volume fraction, no charge carrier tail-to-tail recombination should take place within the amorphous volume fraction of a bottom cell. One may thus expect a bottom cell to be more stable during light soaking than a single junction cell.

In summary, single junction $\mu \mathrm{c}-\mathrm{Si}: \mathrm{H}$ solar cells with a solar energy conversion efficiency of $9.8 \%$ and a $V_{\mathrm{oc}}$ of $603 \mathrm{mV}$ were obtained through a combination of a hot wire buffer layer (affecting the $p$ - $i$ interface) and controlled $\mathrm{SiH}_{4}$ flow profiling (affecting the bulk $i$ layer). The obtained material with a low crystalline volume fraction of $\sim 30 \%$ shows excellent electronic properties and is a promising candidate for use in $\mu \mathrm{c}-\mathrm{Si}: \mathrm{H}$ applications.

The authors thank R. Schmitz, M. Hülsbeck, H. Siekmann, Y. Mai, W. Reetz, H. Stiebig, and R. Carius for fruitful discussions and experimental support. The research of one of the authors (W. M. M. K.) was made possible through a fellowship of the Royal Netherlands Academy of Arts and Sciences (KNAW).

${ }^{1}$ L. Houben, M. Luysberg, P. Hapke, R. Carius, F. Finger, and H. Wagner, Philos. Mag. A 77, 1447 (1998).

${ }^{2}$ J. H. Werner, R. Dassow, T. J. Rinke, J. R. Köhler, and R. B. Bergman, Thin Solid Films 383, 1995 (2001).

${ }^{3} \mathrm{C}$. Wang and G. Lucovsky, Proceedings of the 21st IEEE Photovoltaic Specialists Conference, Kissimmee, FL (1990), p. 1614.

${ }^{4}$ J. Meier, R. Flückiger, H. Keppner, and A. Shah, Appl. Phys. Lett. 65, 860 (1994).

${ }^{5}$ J. Meier, S. Dubail, J. Cuperus, U. Kroll, R. Platz, P. Torres, J. A. Anna Selvan, P. Pernet, N. Beck, N. Pellaton Vaucher, Ch. Hof, D. Fischer, H. Keppner, and A. Shah, J. Non-Cryst. Solids 227-230, 1250 (1998).

${ }^{6}$ J. K. Rath, H. Meiling, and R. E. I. Schropp, Sol. Energy Mater. Sol. Cells 48, 269 (1997).

${ }^{7}$ O. Vetterl, F. Finger, R. Carius, P. Hapke, L. Houben, O. Kluth, A. Lambertz, A. Mück, B. Rech, and H. Wagner, Sol. Energy Mater. Sol. Cells 62, 97 (2000).

${ }^{8}$ B. Rech, T. Repmann, M. N. van den Donker, M. Berginski, T. Kilper, J. Hüpkes, S. Calnan, H. Stiebig, and S. Wieder, Thin Solid Films 511-512, 300 (2006).

${ }^{9}$ A. Matsuda, J. Non-Cryst. Solids 338-340, 1 (2004).

${ }^{10}$ A. Gordijn, J. K. Rath, and R. E. I. Schropp, Prog. Photovoltaics 14, 305 (2006).

${ }^{11}$ A. Shah, J. Meier, E. Vallat-Sauvain, C. Droz, U. Kroll, N. Wyrsch, J. Guillet, and U. Graf, Thin Solid Films 403-404, 179 (2002).

${ }^{12}$ S. Klein, F. Finger, R. Carius, B. Rech, L. Houben, M. Luysberg, and M. Stutzmann, Mater. Res. Soc. Symp. Proc. 715, A26.2 (2002).

${ }^{13}$ Y. Mai, S. Klein, R. Carius, H. Stiebig, X. Geng, and F. Finger, Appl. Phys. Lett. 87, 073503 (2005).

${ }^{14}$ M. N. van den Donker, B. Rech, F. Finger, W. M. M. Kessels, and M. C. M. van de Sanden, Appl. Phys. Lett. 87, 263503 (2005).

${ }^{15}$ G. Yue, B. Yan, G. Ganguly, J. Yang, S. Guha, and C. W. Teplin, Appl. Phys. Lett. 88, 263507 (2006).

${ }^{16}$ J. Zhao, A. Wang, M. A. Green, and F. Ferrazza, Appl. Phys. Lett. 73, 1991 (1998).

${ }^{17}$ M. Taguchi, K. Kawamoto, S. Tsuge, T. Baba, H. Sakata, M. Morizane, K. Uchihashi, N. Nakamura, S. Kiyama, and O. Oota, Prog. Photovoltaics 8, 503 (2000).

${ }^{18}$ O. Schultz, S. W. Glunz, J. C. Goldschmidt, H. Lautenschlager, A. Leimenstoll, E. Scheiderlochner, and G. P. Willeke, Proceedings of the 19th European Photovoltaic Solar Energy Conference, Paris, France (2004), p. 604.

${ }^{19}$ O. Kluth, B. Rech, L. Houben, S. Wieder, G. Schöpe, C. Beneking, H. Wagner, A. Löffl, and H. W. Schock, Thin Solid Films 351, 247 (1999).

${ }^{20}$ B. Rech, T. Roschek, T. Repmann, J. Müller, R. Schmitz, and W. Appenzeller, Thin Solid Films 427, 157 (2003).

${ }^{21}$ M. N. van den Donker, R. Schmitz, W. Appenzeller, B. Rech, W. M. M. Kessels, and M. C. M. van de Sanden, Thin Solid Films 511-512, 562 (2006).

${ }^{22}$ C. Smit, R. A. C. M. M. van Swaaij, H. Donker, A. M. H. N. Petit, W. M. M. Kessels, and M. C. M. van de Sanden, J. Appl. Phys. 94, 3582 (2003).

${ }^{23}$ S. Klein, F. Finger, R. Carius, T. Dylla, B. Rech, M. Grimm, L. Houben, and M. Stutzmann, Thin Solid Films 430, 202 (2003).

${ }^{24}$ Y. Wang, X. Geng, H. Stiebig, and F. Finger, Technical Digest of the Fourth International Conference On Hot-Wire (Cat-CVD) Process Takayama, Japan (2006), p. 321. 